\title{
Surgical Removal of Necrosed Venom Gland in Indian Spectacled Cobra (Naja naja)- A Case Report
}

\author{
Rohit RAJ ${ }^{1}$, Prasenjit MUKHERJEE ${ }^{2}$, Shubhamitra CHAUDHURI ${ }^{3}$, Siddhartha BASU ${ }^{4}$, Uttam DATTA ${ }^{5}$ \\ ${ }^{1}$ M.V.Sc Scholar, Department of Veterinary Gynaecology and Obstetrics, W.B.U.A.F.S., Kolkata, India; \\ ${ }^{2}$ Department of T.V.C.C., Faculty of Veterinary and Animal Sciences, W.B.U.A.F.S., Kolkata, India; \\ ${ }^{3}$ Department of T.V.C.C., Faculty of Veterinary and Animal Sciences, W.B.U.A.F.S., Kolkata, India; \\ Department of Veterinary Gynaecology and Obstetrics, Faculty of Veterinary and Animal Sciences, \\ W.B.U.A.F.S., Kolkata, India \\ ${ }^{5}$ Department of Veterinary Gynaecology and Obstetrics, Faculty of Veterinary and Animal Sciences, \\ W.B.U.A.F.S., Kolkata, India \\ * corresponding author: vetprasenjit@gmail.com
}

Bulletin UASVM Veterinary Medicine 74(1) / 2017,

Print ISSN 1843-5270; Electronic ISSN 1843-5378

DOI:10.15835/buasvmcn-vm: 12307

\begin{abstract}
An Indian spectacled cobra (Naja naja) with necrosed venom gland along with soft tissue mass was successfully removed surgically under general anesthesia by ketamine hydrochloride $(50 \mathrm{mg} / \mathrm{kg})$. Post operative care and management were performed by keeping the animal in captivity. Inj. Enrofloxacin ${ }^{\circledR}(10 \mathrm{mg} / \mathrm{kg})$ and Inj. Meloxicam ${ }^{\circledR}(0.2 \mathrm{mg} / \mathrm{kg})$ were administered post operatively. The snake was set free in the wild after complete recovery.
\end{abstract}

Keywords: snake, Indian cobra, necrosed venom gland, surgical excision

\section{INTRODUCTION}

In India, around 200 species of snakes are found and which constitutes approximately 10 percent of worlds' total snake population. Snakes in most parts of the country are worshipped but they also get stricken due to unawareness and fear amongst people. The present study reports successful surgical removal of necrosed tissue mass with venom gland in a rescued common Indian spectacled cobra (Naja naja). N. naja is an endangered species under schedule II (Part II), Indian Wild life (Protection) Act, 1972.

\section{AIMS AND OBJECTIVES}

The objective of this work was to describe surgical removal of necrosed venom gland with soft tissue mass and post operative treatment and management in an injured Indian cobra.

\section{MATERIALS AND METHODS}

One injured cobra about $5 \mathrm{ft}$ long and $2.5 \mathrm{~kg}$ in weight was rescued, trapped in a cage and brought to the Veterinary Clinical Complex. The snake was restrained inside a snake tube for clinical observations. Careful observations revealed that there was a protruded necrosed venom gland with soft tissue massin the leftside (Fig. 1) and suggested for surgical intervention. For anaesthesia, ketamine hydrochloride $(50 \mathrm{mg} / \mathrm{kg}$ IM; Themis Medicare, India) was injected intramuscularly at dorsal apaxial muscle. The mouth alongwith gland and tissue mass were washed with $10 \%$ povidone iodine oral solution [®Win Medicare, India] after $5 \mathrm{~min}$. of anaesthesia. The necrosed venom gland with tissue mass was ligated with 2-0 chromic catgut (Alworth et al., 2011). Surgical incision was given to remove the whole ligated mass (Fig. 2). 


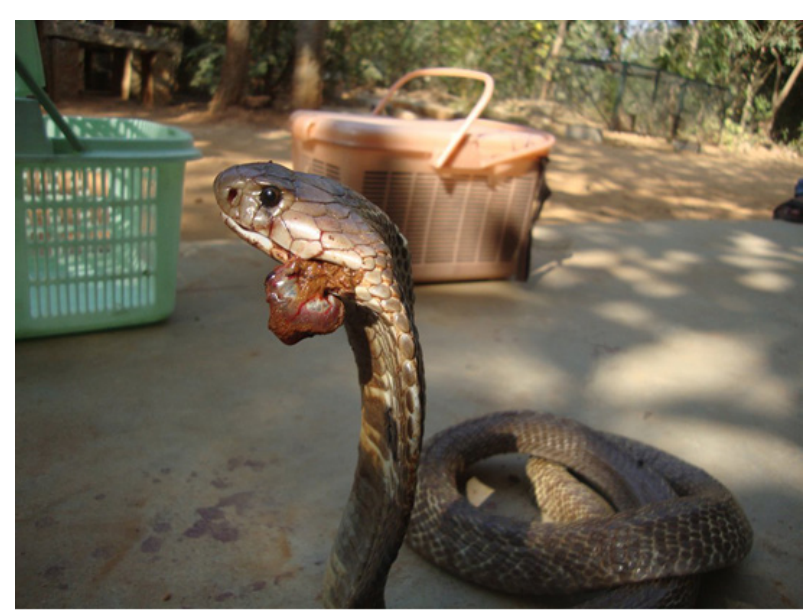

Fig. 1. Necrosed venom gland with tissue mass in Indian spectacled cobra (Naja naja).

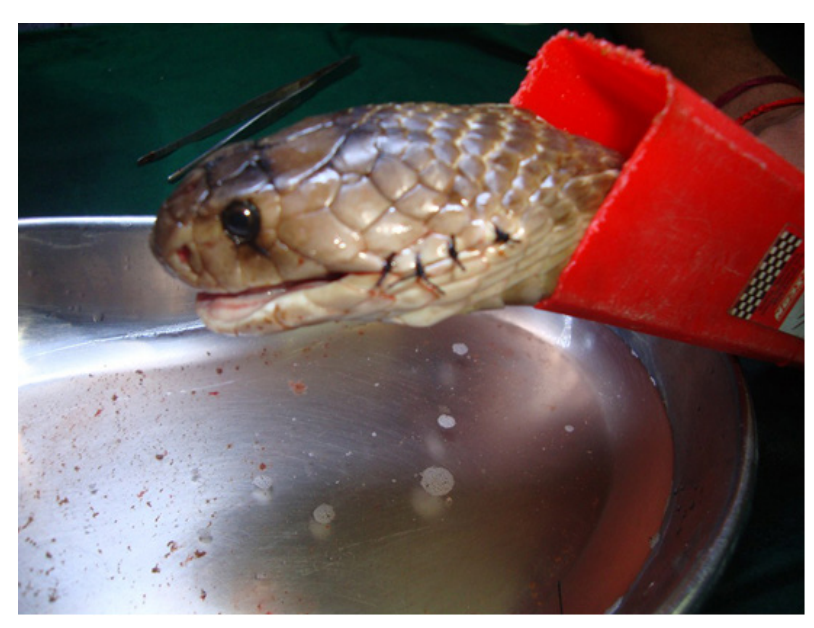

Fig. 3. Skin sutured after surgical removal of necrosed venom gland with tissue mass.

Skin wound adjacent to the gland was repaired using braided silk No. 1-0 with simple interrupted suture pattern (Fig. 3). The snake was injected parenterally with enrofloxacin $(10 \mathrm{mg} / \mathrm{kg}$ IM; Pfizer Animal Health India Ltd) for consecutive 5 days and 2 applications of Inj. Meloxicam (0.2 $\mathrm{mg} / \mathrm{kg}$ IM; Intas Pharmaceuticals Ltd., India) were administered in every $48 \mathrm{~h}$ interval to achieve analgesia. Snake was kept in captivity upto 15 post-operative day and fed with minced chicken meat soaked in glucose during this period. There was uneventful recovery and skin suture was removed 10 days postoperatively (Fig. 4).

\section{RESULTS}

Injection ketamine hydrochloride $(50 \mathrm{mg} /$ $\mathrm{kg}$ ) produced smooth induction of anaesthesia

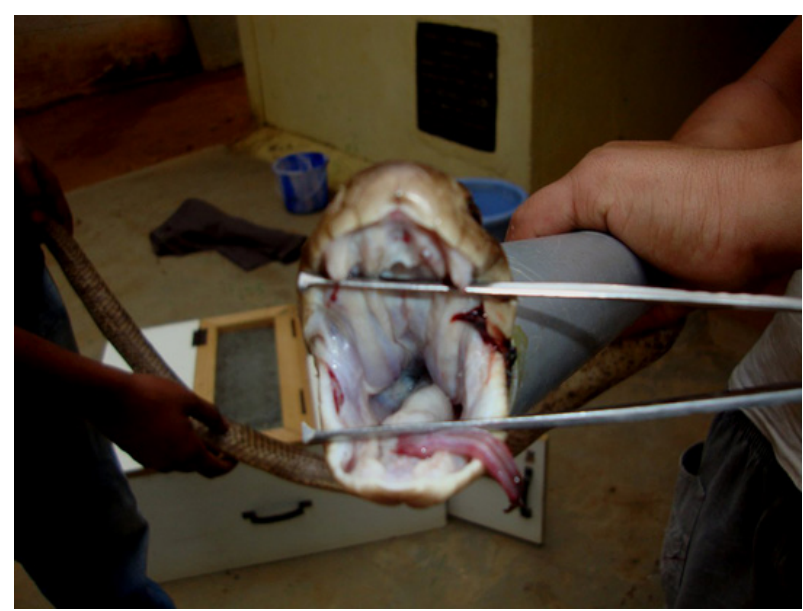

Fig. 2. Oral cavity after surgical removal of necrosed venom gland with tissue mass.

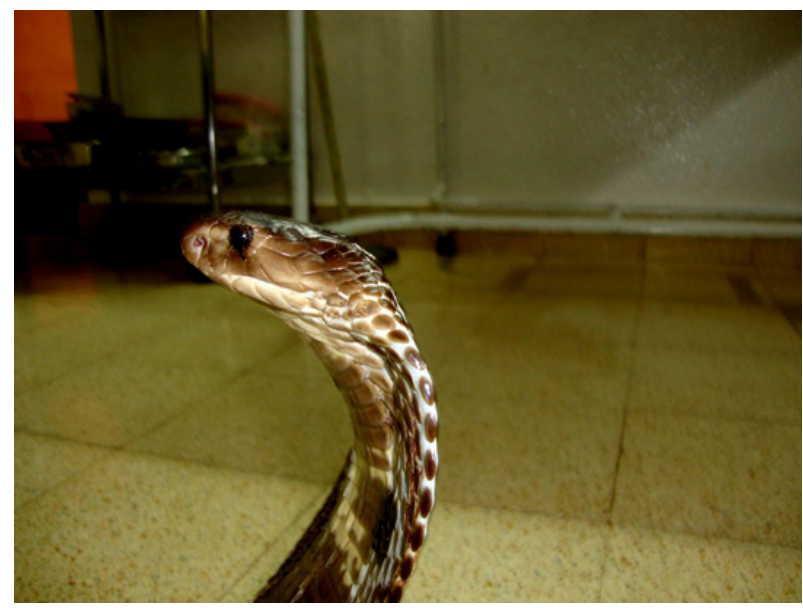

Fig. 4. Complete healing after surgical removal of necrosed venom gland with tissue mass.

within $5 \mathrm{~min}$. Post-operative treatment with inj.enrofloxacin $(10 \mathrm{mg} / \mathrm{kg})$ as antibiotic for consecutive 5 days and inj. meloxicam $(0.2 \mathrm{mg} / \mathrm{kg})$ as analgesic for 2 days resulted complete recovery to the operated snake. The snake was given new lease of life and set free in its natural habitat.

\section{DISCUSSION}

The reason for venom gland trauma and necrosis in this case may be due to fight. Complete surgical removal of venom gland in poisonous snake has not been reported previously in India. For anaesthesia, ketamine hydrochloride @ 40-80 mg/kg IM may be used as injectable anaesthetic as it produce peripheral analgesia as well as tranquilization in snake (Benett 1996; Bouts and Gasthus 2002). In present study, 
ketamine hydrochloride (50 mg/kg; IM) produced desirable analgesia and the snake recovered after $90 \mathrm{~min}$. that corroborated with the findings of Bennett (1991). Use of enrofloxacin was found to be effective to control bacterial infection as it has activity against gram-negative organisms implicated in serious infectious diseases of reptile species with a rapid and concentration-dependent bactericidal effect (Waxman et al., 2014). In this case meloxicam was used as NSAID, which works mainly peripherally decreasing prostanoids that facilitates the generation and conduction of pain impulses (Bouts and Gasthus, 2002). It also helps to reduce pain of somatic origin (Thurmon et al., 2007). Surgical removal of venom gland did not affect general health condition or feeding habit of snake which also simulated with the findings of Glenn et al. (1973).

\section{CONCLUSION}

This report describes the successful removal of protruded necrosed venom gland with soft tissue mass in a Naja naja first time in India.

\section{REFERENCES}

1. Alworth LC, Hernandez SM, Divers SJ (2011). Laboratory Reptile Surgery: Principles and Techniques. J Am Assoc Lab Anim Sci 50(1): 11-26.

2. Benett RA (1991). A review of anaesthesia and chemical restraint in reptiles. J Zoo Wildl Med 22(3): 282-303.

3. Benett RA (1996). Anaesthesia, p.241-247. In: Mader DR. (ed.). Reptile medicine and surgery. W.B. Saunders, Philadelphia, USA.

4. Bouts T, Gasthuys F (2002). Anaesthesia in reptiles. Vlaams Diergeneeskundig Tijdschrift 71: 183-194.

5. Glenn JL, Straight R, Snyder CC (1973). Surgical technique for isolation of the main venom gland of viperid, crotalid and elapid snakes. Toxicon 11(3): 231-232.

6. The Wildlife (Protection) ACT, 1972 (No. 53 of 1972). Published on $9^{\text {th }}$ September, 1972, India.

7. Thurmon JC, Tranquilli WJ, Benson GJ (2007). Perioperative pain and distress, p. 40-61. In: William JT, John CT, Kurt AG (eds), Lumb \& Jones' Veterinary Anaesthesia and Analgesia, $4^{\text {th }}$ edn., Blackwell Publishing Professional 2121, State Avenue, Ames, Iowa.

8. Waxman S, Prados AP, de Lucas JJ, San Andrés MI, Regner P, de Oliveira VC, de Roodt A Rodríguez C (2014). Pharmacokinetic behavior of enrofloxacin and its metabolite ciprofloxacin in Urutu pit vipers (Bothrops alternatus) after intramuscular administration. J Zoo Wildl Med 45(1): 78-85. 